\title{
Skeletal muscle metabolism during prolonged exercise in Pompe disease
}

\author{
Nicolai Preisler', Pascal Laforêt ${ }^{2}$, Karen Lindhardt Madsen', Edith Husu', \\ Christoffer Rasmus Vissing', Gitte Hedermann', Henrik Galbo ${ }^{3}$, \\ Christopher Lindberg ${ }^{4}$ and John Vissing ${ }^{1}$
}

${ }^{1}$ Copenhagen Neuromuscular Center, Department of Neurology, Rigshospitalet, University of Copenhagen, Copenhagen, Denmark

${ }^{2}$ Centre de Référence de Pathologie Neuromusculaire Paris-Est, Institut de Myologie, GH Pitié-Salpêtrière, Assistance Publique-Hôpitaux de Paris, Paris, France

${ }^{3}$ Department of Inflammation Research, Rigshospitalet, Copenhagen, Denmark

${ }^{4}$ Department of Neurology, Sahlgrenska University Hospital, Gothenburg, Sweden

Correspondence

should be addressed

to $\mathrm{N}$ Preisler

Email

npreisler@hotmail.com

\begin{abstract}
Objective: Pompe disease (glycogenosis type II) is caused by lysosomal alpha-glucosidase deficiency, which leads to a block in intra-lysosomal glycogen breakdown. In spite of enzyme replacement therapy, Pompe disease continues to be a progressive metabolic myopathy. Considering the health benefits of exercise, it is important in Pompe disease to acquire more information about muscle substrate use during exercise.

Methods: Seven adults with Pompe disease were matched to a healthy control group (1:1). We determined (1) peak oxidative capacity $\left(\mathrm{VO}_{2 \text { peak }}\right)$ and (2) carbohydrate and fatty acid metabolism during submaximal exercise $(33 \mathrm{~W})$ for $1 \mathrm{~h}$, using cycle-ergometer exercise, indirect calorimetry and stable isotopes.

Results: In the patients, $\mathrm{VO}_{2 \text { peak }}$ was less than half of average control values; mean difference $-1659 \mathrm{~mL} / \mathrm{min}(\mathrm{Cl}:-2450$ to $-867, P=0.001)$. However, the respiratory exchange ratio increased to $>1.0$ and lactate levels rose 5 -fold in the patients, indicating significant glycolytic flux. In line with this, during submaximal exercise, the rates of oxidation (ROX) of carbohydrates and palmitate were similar between patients and controls (mean difference $0.226 \mathrm{~g} / \mathrm{min}(\mathrm{Cl}: 0.611$ to $-0.078, P=0.318$ ) and mean difference $0.016 \mu \mathrm{mol} / \mathrm{kg} / \mathrm{min}(\mathrm{Cl}: 1.287$ to $-1.255, P=0.710)$, respectively).

Conclusion: Reflecting muscle weakness and wasting, Pompe disease is associated with markedly reduced maximal exercise capacity. However, glycogenolysis is not impaired in exercise. Unlike in other metabolic myopathies, skeletal muscle substrate use during exercise is normal in Pompe disease rendering exercise less complicated for e.g. medical or recreational purposes.
\end{abstract}

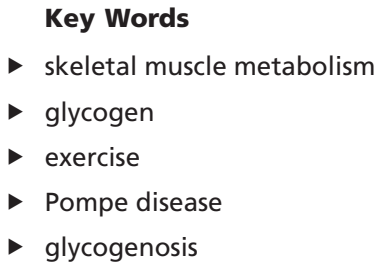

Endocrine Connections (2017) 6, 384-394

\section{Introduction}

Pompe disease (Glycogenosis type II; OMIM \#232300) is caused by lysosomal acid alpha-glucosidase deficiency (EC\# 3.2.1.20), which leads to a metabolic block in intralysosomal glycogen breakdown (1). In the late-onset forms of Pompe disease, morbidity and mortality are mainly caused by progressive skeletal muscle weakness and wasting (2). Even though treatment with recombinant acid alpha-glucosidase improves walking distance and lung function, and slows down disease progression rate and improves life expectancy, Pompe disease continues http://www.endocrineconnections.org DOI: 10.1530/EC-17-0042 (c) 2017 The authors Published by Bioscientifica Ltd

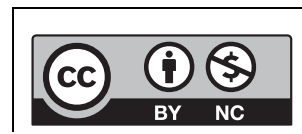

This work is licensed under a Creative Commons Attribution-NonCommercial 4.0 International License. 
to be a progressive metabolic myopathy $(3,4)$. Therefore, new treatments are continuously being investigated in Pompe disease. Exercise is one intervention, which has the potential to improve skeletal muscle function in lateonset forms of Pompe disease (5).

Glycogen is an essential source of energy for skeletal muscle during exercise (6). Exercise may increase skeletal muscle energy requirements many fold, and therefore exercise may be used as a tool to unmask unrecognized derangements in muscle substrate turnover in patients with metabolic myopathies $(5,7,8,9,10,11,12)$. Unmasking such derangements may be used to determine what types of exercises may be tolerated and whether or not substrate supplementation might improve exercise tolerance. Recently, it has been suggested that patients with Pompe disease are in a state of 'chronic energy deficiency' at rest (13). An energy deficiency at rest is likely to be exaggerated by exercise. However, substrate turnover during moderate intensity exercise has not been studied in patients with Pompe disease.

We therefore wanted to determine the maximal aerobic exercise capacity and to measure substrate turnover during prolonged (i.e. $1 \mathrm{~h}$ ) moderate intensity exercise, in patients with Pompe disease. We used cycleergometer exercise and stable isotope methodology in combination with indirect calorimetry to determine glucose, glycerol, and fatty acid metabolism during exercise, and we measured body composition with dual X-ray absorptiometry (DEXA) scanning, to determine the lean body mass.

\section{Materials and methods}

\section{Subjects}

We included 7 patients older than 18 years with genetically and biochemically verified Pompe disease. The patients were matched by gender, age and body mass index (BMI) to a sedentary healthy control group (1:1). Data from 3 of the controls in this study have been used as reference material for another study of glycogen debrancher deficiency (12) (Table 1).

\section{Study design, setting and outcomes}

The study was a case-control designed study, performed on 2 consecutive days, in our exercise laboratory in
Copenhagen. Subjects were tested from December 2011 to January 2014. The primary outcomes of the peak exercise test were to assess differences in peak oxidative capacity and concentrations of plasma lactate after peak exercise in patients vs controls. The primary outcomes during submaximal exercise were differences in the average rate of oxidation (ROX) of carbohydrates, palmitate and non-esterified fatty acids (NEFA), and the rates of appearance of glucose and glycerol in patients vs controls.

\section{Exclusion criteria}

Patients with serious heart or lung conditions contraindicating exercise testing as well as concomitant disorders or participation in other trials, which might interfere with the metabolic studies, were disqualified from participation.

\section{Dual-Energy X-ray Absorptiometry scanning (day 1)}

A whole-body DEXA scan (Prodigy Advance, GE Healthcare Lunar, software version 14.10.022) was performed to determine the body composition of the subjects. The subjects arrived in the laboratory in the morning after $3 \mathrm{~h}$ of fasting, and they drank $0.5 \mathrm{~L}$ of water $30 \mathrm{~min}$ before the DEXA scan, in order to be well hydrated before peak exercise testing. Prior to DEXA scanning, the subjects voided urine. The subjects were tested wearing underwear only. Quality control was performed with a QC Phantom, Lunar AI in water.

\section{Peak exercise testing (day 1)}

Following the DEXA scan, the subjects performed a graded exercise test to exhaustion on a cycle-ergometer (Excalibur Sport, Lode BV, Groningen, the Netherlands) to determine peak oxidative capacity $\left(\mathrm{VO}_{2 \text { peak }}\right)$, and plasma lactate and glucose concentrations at exhaustion. Blood samples were drawn before and immediately after exercise from an indwelling venous catheter. A 3-lead ECG and a pulse transmitter belt monitored heart rate, and pulmonary gas-exchange was measured with breathby-breath indirect calorimetry (Quark CPET, Cosmed Srl, Milan, Italy). Blood to measure plasma creatine kinase (CK) was sampled before exercise, and again the following day (with background samples). http://www.endocrineconnections.org
DOI: 10.1530/EC-17-0042
() 2017 The authors Published by Bioscientifica Ltd
This work is licensed under a Creative Commons Attribution-NonCommercial 4.0 International License. 


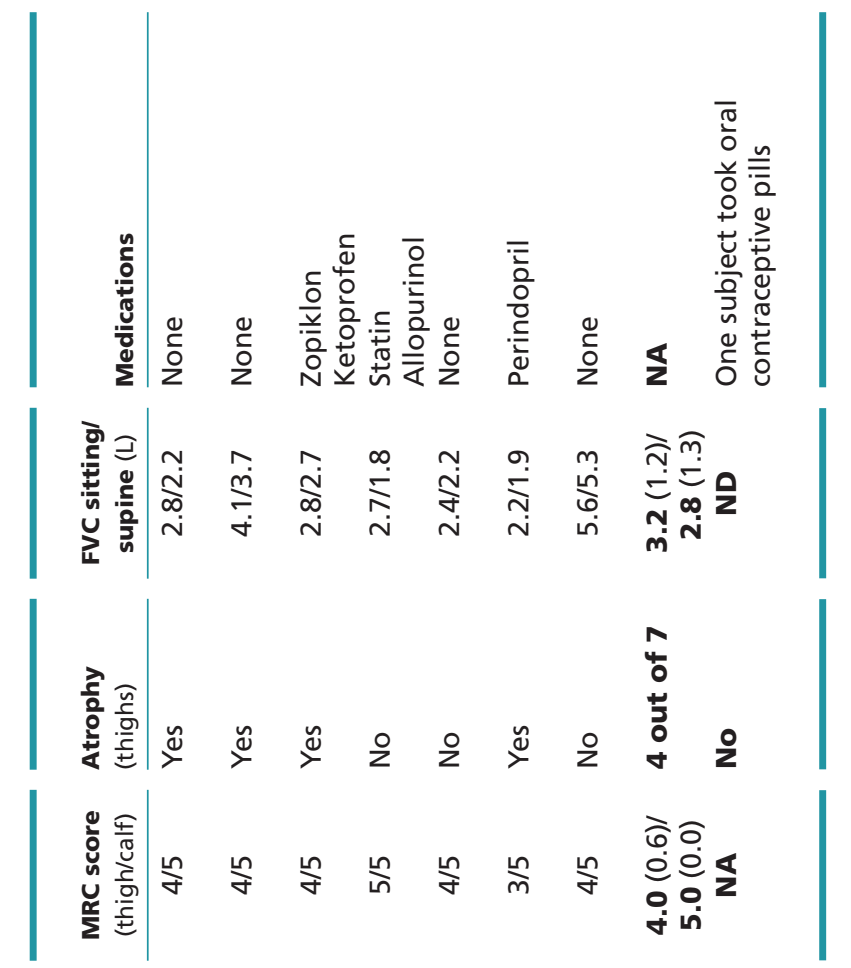

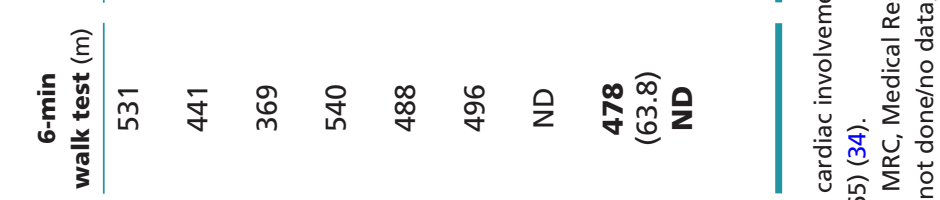

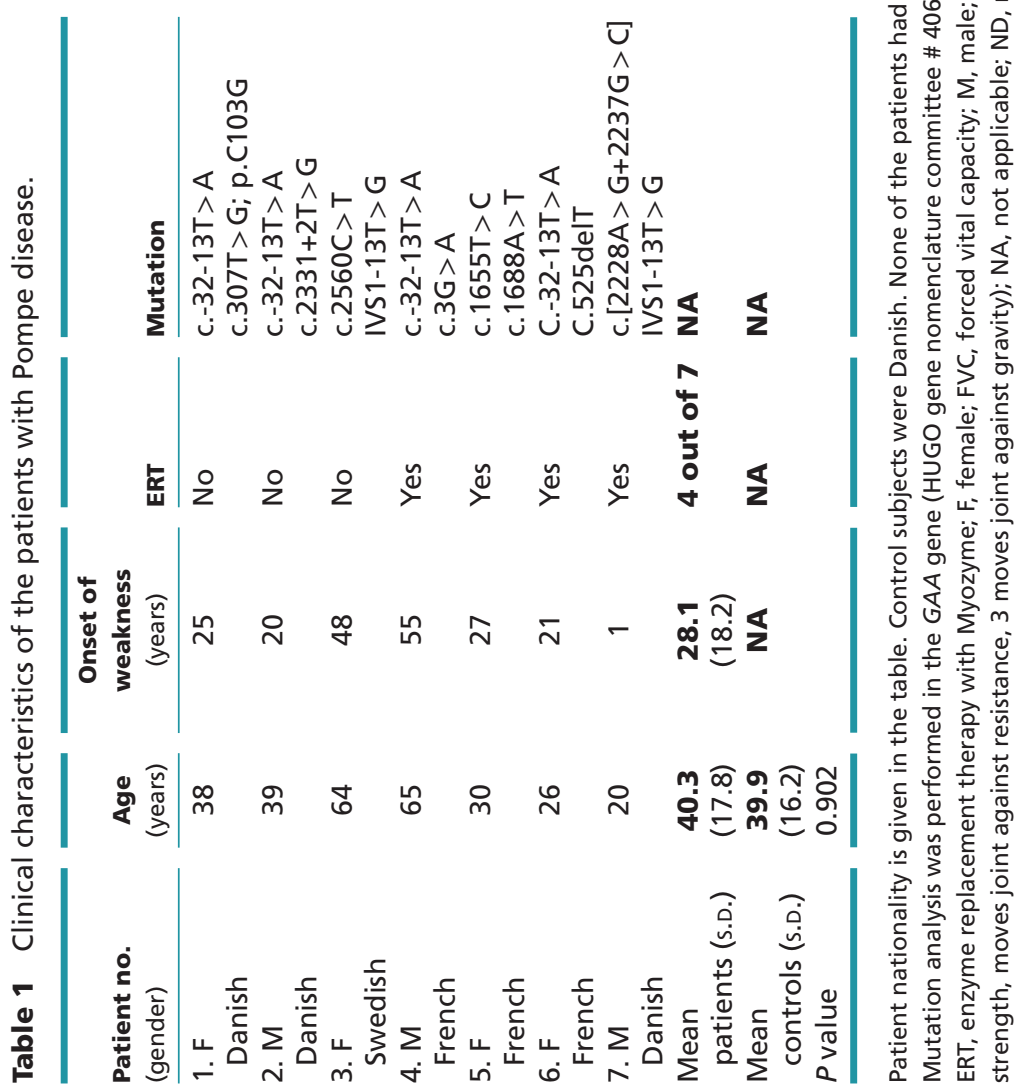




\section{Whole-body substrate turnover during submaximal cycle ergometer exercise (day 2)}

The subjects arrived in the laboratory in the morning after an overnight fast. Catheters were inserted in the cubital vein in one arm for stable isotope infusion and in a hand vein on the opposite limb for blood sampling. A heating pad was wrapped around the hand to arterialize the venous blood (14). Background blood and breath samples were collected, expired air being sampled in an airtight collection bag (Hans Rudolph, Inc., KS, USA) for measurement of ${ }^{13} \mathrm{CO}_{2} /{ }^{12} \mathrm{CO}_{2}$. Subsequently, a primed constant rate infusion of stable isotope tracers was started; $\left[\mathrm{U}-{ }^{13} \mathrm{C}\right]$-palmitate $(0.010 \mu \mathrm{mol} / \mathrm{kg} / \mathrm{min}$, bound to albumin and primed by $\mathrm{NaH}^{13} \mathrm{CO}_{3}, 1.0 \mu \mathrm{mol} /$ $\mathrm{kg}), \quad\left[6,6-\mathrm{D}_{2}\right]$-glucose $(0.40 \mu \mathrm{mol} / \mathrm{kg} / \mathrm{min}$, primed by $13 \mu \mathrm{mol} / \mathrm{kg})$ and $\left[1,1,2,3,3-\mathrm{D}_{5}\right]$-glycerol $(0.053 \mu \mathrm{mol} / \mathrm{kg} /$ min, primed by $0.795 \mu \mathrm{mol} / \mathrm{kg})$. Infusions were delivered by a Gemini PC2 pump (IMED, San Diego, CA, USA) and continued for $2 \mathrm{~h}$ before exercise began. Breath and blood samples were drawn simultaneously $20 \mathrm{~min}$ before exercise and then repeatedly every $10 \mathrm{~min}$ until the end of exercise. Ten minutes before exercise, the subject was seated on the cycle-ergometer, equipped with ECG electrodes and a pulse transmitter, and a facial mask connected to the indirect calorimetry system. Pulmonary gas exchange was measured for 2 min before blood and breath samples were collected. One minute before blood sampling, the facial mask was removed to allow for the washout and collection of breath for ${ }^{13} \mathrm{CO}_{2}$ measurements. At the onset of exercise, the infusion rate of isotopes was doubled to avoid marked decreases in tracer enrichments. Heart rate and rate of perceived exertion (RPE, visual analog (Borg) scale from 6 to 20) were recorded every other minute during exercise (15). The patients exercised at a workload corresponding to $\sim 60 \%$ of their $\mathrm{VO}_{2 \text { peak }}$, whereas the controls exercised at the same absolute workload as the patients.

\section{Analysis of blood samples}

Blood was drawn in syringes containing heparin and was analyzed for lactate and glucose concentrations within 10 min on an ABL-725 system (Radiometer, Copenhagen, Denmark). Enrichments of plasma glucose and glycerol and the glycerol concentration were analyzed simultaneously by liquid chromatography-tandem mass spectrometry (LC-MS/MS), modified according to Oehlke (16). ${ }^{13} \mathrm{CO}_{2}$-breath enrichment and plasma palmitate enrichment and concentration were analyzed by gas chromatography-isotope-ratio mass spectrometry (Finnigan MAT, Bremen, Germany). NEFAs were analyzed with a spectrophotometry kit (NEFA-HR(2), Wako Chemical Gmbh, Germany). Insulin and catecholamines were measured at rest and after exercise with enzymelinked immunosorbent assays (Insulin ELISA kit, Dako, Glostrup, Denmark, and 2-CAT plasma ELISA kit, Labor Diagnostica Nord GmbH \& Co) and a Modulus II Microplate Multimode Reader (Turner Biosystems, Inc., Sunnyvale, CA, USA). Blood to measure plasma CK was collected in lithium-heparin coated tubes and was analyzed by an enzymatic assay and spectrophotometry in the Clinical Biochemical Department.

\section{Substrate turnover calculations}

The rates of appearance $\left(\mathrm{R}_{\mathrm{a}}\right)$ and disappearance $\left(\mathrm{R}_{\mathrm{d}}\right)$ of palmitate, glucose and glycerol at rest and during exercise were calculated using the non-steady-state equations of Steele adapted for the use of stable isotopes (17). $R_{\mathrm{a}}(\mu \mathrm{mol} / \mathrm{kg} / \mathrm{min})$

$$
\begin{aligned}
& =\frac{F-V \times\left(\left(C_{n}+C_{n+1}\right) / 2\right) \times\left(\left(E_{n+1}-E_{n}\right) /\left(t_{n+1}-t_{n}\right)\right)}{\left(\left(E_{n+1}+E_{n}\right) / 2\right)} \\
& R_{\mathrm{d}}(\mu \mathrm{mol} / \mathrm{kg} / \mathrm{min})=R_{\mathrm{a}}-V \times\left(\left(C_{n+1}-C_{n}\right) /\left(t_{n+1}-t_{n}\right)\right)
\end{aligned}
$$

Plasma palmitate ROX $(\mu \mathrm{mol} / \mathrm{kg} / \mathrm{min})$

$$
=\frac{\left(\mathrm{V}_{\mathrm{CO} 2} \times \mathrm{TTR}_{\text {breath }} / 16\right)}{\mathrm{TTR}_{\text {palmitate }} \times \text { acetate correction factor } / 100}
$$

$F=$ infusion rate $(\mu \mathrm{mol} / \mathrm{min} / \mathrm{kg}), \quad E=$ enrichment (tracer to tracee ratio), $C=$ concentration $(\mu \mathrm{mol} / \mathrm{L}), n$ and $n+1=$ adjacent samples, $\mathrm{V}_{\mathrm{CO} 2}=\mathrm{CO}_{2}$ production $(\mu \mathrm{mol} / \mathrm{kg} / \mathrm{min}), \quad \mathrm{TTR}_{\text {breath }}={ }^{13} \mathrm{CO}_{2} /{ }^{12} \mathrm{CO}_{2}$ ratio in breath, TTR palmitate $={ }^{13} \mathrm{C} /{ }^{12} \mathrm{C}$ palmitate ratio in plasma, $t=$ sample time ( $\mathrm{min}), \quad V=$ volume of distribution (palmitate $=0.04 \mathrm{~L} / \mathrm{kg}, \quad$ glucose $=0.145 \mathrm{~L} / \mathrm{kg} \quad$ and glycerol $=0.230 \mathrm{~L} / \mathrm{kg}$ ). An acetate correction factor was applied $($ rest $=27 \%$; exercise $=78 \%)(18,19)$.

\section{Indirect calorimetry}

Fat and carbohydrate oxidation rates were calculated using non-protein respiratory exchange ratio (RER) equations adapted for moderate intensity exercise (20).

Whole-body carbohydrate oxidation (ROX) in $\mathrm{g} / \mathrm{min}=4.210 \times \mathrm{V}_{\mathrm{CO} 2}-2.962 \times \mathrm{V}_{\mathrm{O} 2}$. 
Whole-body fat oxidation (ROX) in $\mathrm{g} / \mathrm{min}=1.695 \times \mathrm{V}_{\mathrm{O} 2}-1.701 \times \mathrm{V}_{\mathrm{CO} 2}$.

Total NEFA oxidation rates were calculated by converting the rate of total fat oxidation to its molecular equivalent with the assumption that the average molecular weight of triglyceride is $860 \mathrm{~g} / \mathrm{mol}$ and multiplying the molar rate of triglyceride oxidation by 3 because each molecule contains 3 fatty acid residues.

\section{Ethics and statistics}

The study was conducted in accordance with the Declaration of Helsinki and was approved by the Regional Ethical Committee of the Capital Region of Denmark (\#H-2-2010-008, with amendment \#39559). The subjects gave written informed consent prior to inclusion. Median resting and exercise values (averages from the whole exercise period), and body composition measurements were compared between patients and controls with a Mann-Whitney rank sum test, and CK levels in the patients before and after peak exercise with a Signed rank test. A $P$ value $<0.05$ was considered significant (twotailed testing). Results are reported as mean \pm s.D. (unless otherwise stated), and with 95\% Confidence Intervals (CIs) of the mean for the primary outcomes (calculated with an un-paired $t$-test). Data from a previous study were used to estimate sample size, and PS Power and Sample Size, version 3.0.0.43. was used to calculate the sample size for the primary outcomes $(21,22)$. Statistical analysis was performed with SigmaPlot version 11.0.

\section{Results}

\section{Body composition}

The patients tended to weigh less than controls, 64.6 (s.D. 13.2) vs 75.8 (s.D. 15.2) kg; however, the two groups had similar BMIs (Fig. 1). Nevertheless, patients tended to have a higher \% body fat and a lower \% lean body mass than controls (Fig. 1), and, consequently, a similar total fat mass (patients 23.9 (s.D. 10.3) $\mathrm{kg}$ and controls 22.2 (s.D. $6.1) \mathrm{kg}, P=0.805$ ) and a lower lean tissue mass (38.2 (s.D. $6.8) \mathrm{kg}$ vs 50.5 (s.D. 11.9) kg, $P=0.073$ ).

\section{Peak exercise testing}

The peak work load, $\mathrm{W}_{\text {peak }}$, was lower in the patients than in controls, $92.9 \mathrm{~W}$ (s.D. 48.4 ; range: $50-150$ ) vs $264.3 \mathrm{~W}$ (s.D. 70.2; range: $160-370), P<0.001)$. In accordance with this, the patients' absolute $\mathrm{VO}_{2 \text { peak }}$ was less than half of average control values (Fig. 2), and even though the patients tended to weigh less, adjusting the $\mathrm{VO}_{2 \text { peak }}$ for body weight (fitness rating) only minimally affected this difference: The fitness rating of patients was $28.8 \mathrm{~mL} /$ $\mathrm{kg} / \mathrm{min}$ (s.D. 8.9 ; range: $17.7-43.7$ ) vs $43.4 \mathrm{~mL} / \mathrm{kg} / \mathrm{min}$ (s.D. 6.4; range: $35.7-52.6)$ in controls, $P=0.007$. Lactate levels at rest were similar between groups; however, at time of exhaustion, blood lactate levels had increased significantly less in the patients (Fig. 2). The blood glucose levels were similar at rest $(5.3 \mathrm{mmol} / \mathrm{L}$ (s.D. 0.8; range: 4.2-6.4) and 5.3 mmol/L (s.D. 0.6; range: 4.9-6.6)) as well as after peak exercise $(5.9 \mathrm{mmol} / \mathrm{L}$ (s.D. 1.2 ; range: $4.8-7.2)$ and $6.1 \mathrm{mmol} / \mathrm{L}$ (s.D. 0.6; range: $5.4-7.2$ )) in patients and controls, respectively.

The RER increased to $\geq 1.0$ in all subjects during peak exercise, and there was no difference between patients, 1.11 (s.D. 0.07; range: $1.00-1.22$ ) and the controls, 1.11 (s.D. 0.07; range: $1.02-1.23)$ at time of $\mathrm{VO}_{2 \text { peak }}(P=1.00)$. The day after peak exercise, the average plasma CK level had not increased. However, in patient no. 6, who had the highest baseline CK level, CK increased by 33\% (Fig. 2). Average heart rate at rest (79.6 (s.D. 16.0) vs 72.6 (s.D. 11.1) beats/min, $P=0.535)$ and at time of exhaustion (176.0 (s.D. 18.2) vs 179.6 (s.D. 7.6) beats/min, $P=1.000$ ) did not
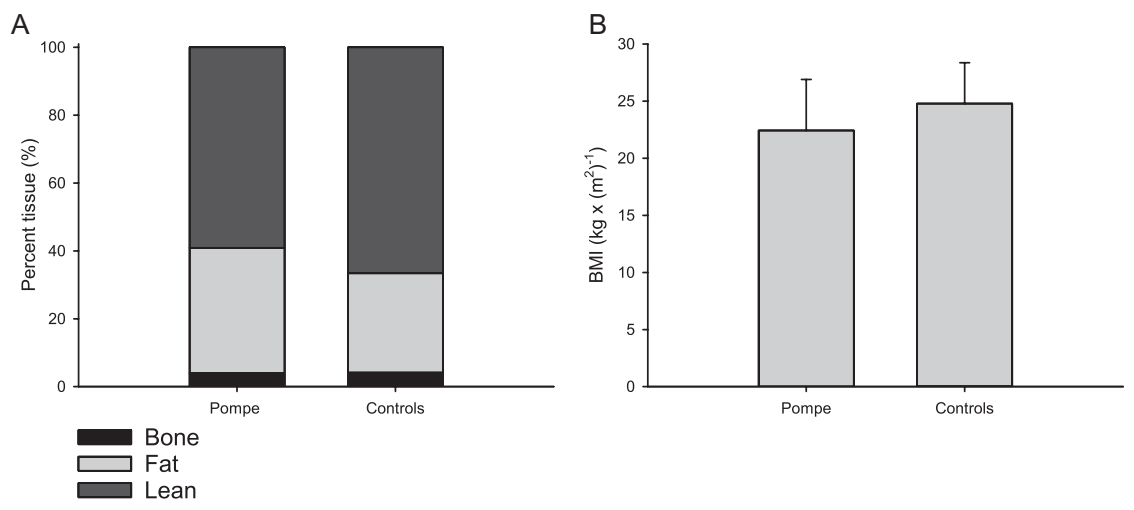

http://www.endocrineconnections.org DOI: 10.1530/EC-17-0042 (c) 2017 The authors Published by Bioscientifica Ltd
Figure 1

Body composition and BMI. (A) Body composition in patients and controls. The patients tended to have a higher percentage of body fat, 37.5 (s.D. $11.5) \%$, compared to controls, 30.7 (s.D. 6.4) \%, $(P=0.097)$, and in accordance with this a lower lean tissue mass 38.2 (s.D. 6.8) kg vs 50.5 (s.D. 11.9) $\mathrm{kg}$ in controls $(P=0.073)$. (B) There was no difference in the body mass index (BMI), between patients 22.4 (s.D. 4.5) $\mathrm{kg} / \mathrm{m}^{2}$ and controls 24.8 (S.D. 3.6) $\mathrm{kg} / \mathrm{m}^{2},(P=0.318)$. Error bars are S.D. 

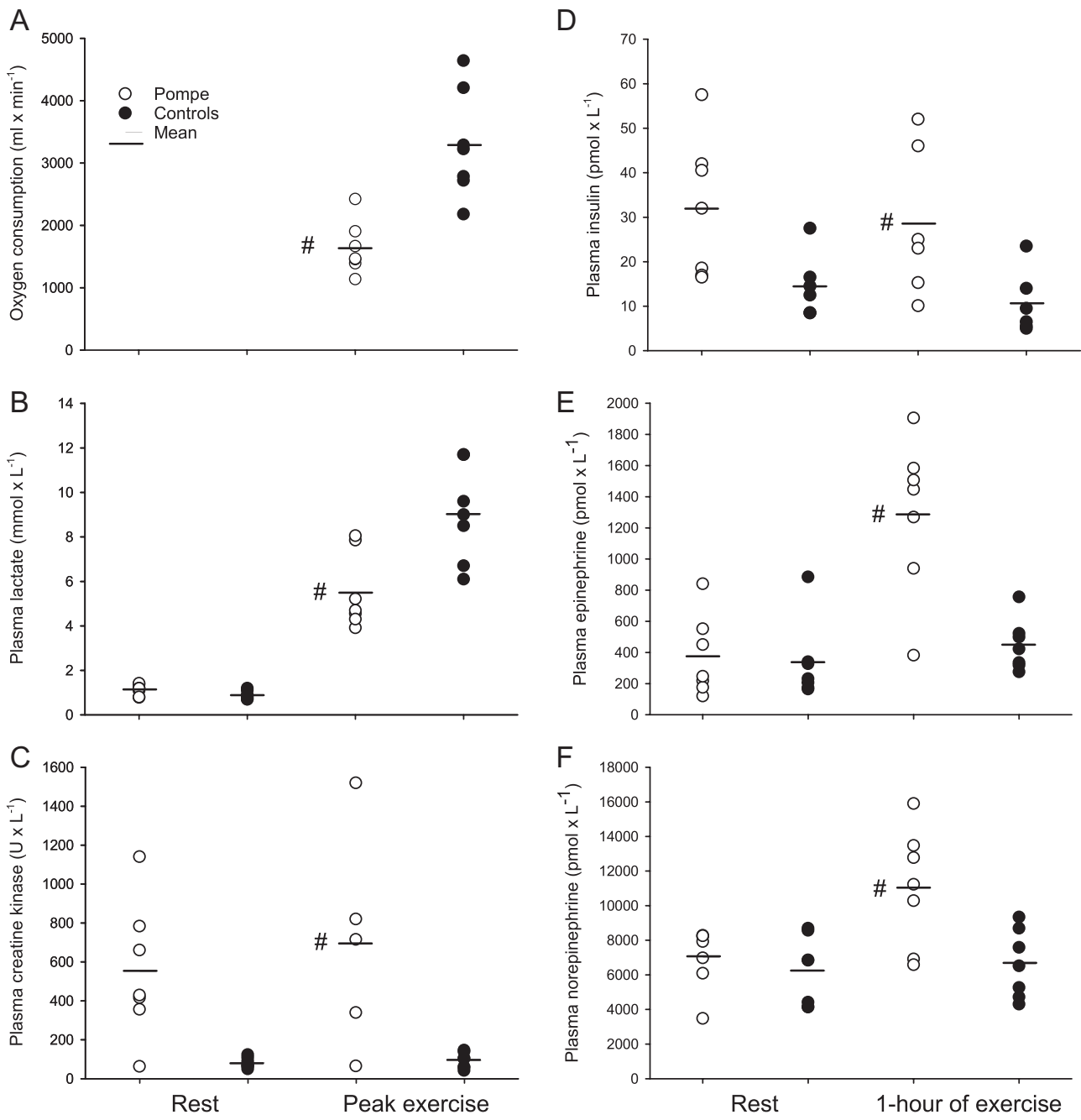

Figure 2

Peak exercise testing, plasma creatine kinase levels and hormones. (A) Peak oxygen uptake was significantly lower in the patients; mean difference $-1659 \mathrm{~mL} / \mathrm{min}(\mathrm{Cl}:-2450$ to $-867, P=0.001)$. (B) Plasma lactate levels increased less in the patients than in controls, after peak exercise; mean difference $-3.5 \mathrm{mmol} / \mathrm{L}(\mathrm{Cl}:-5.8$ to $-1.2, P=0.007)$. (C) Average plasma CK levels, assessed in 5 patients, did not increase after peak exercise, 600 (s.D. 411$)$ baseline vs 692 (s.D. 552) U/L 1-day post exercise, mean difference of $91 \mathrm{U} / \mathrm{L}$ (Cl: 295 to $-112, P=0.188)(P=0.28)$. (D) Insulin levels were within normal range, both at rest and after $1 \mathrm{~h}$ of submaximal exercise, but levels were higher after exercise in patients vs controls; mean difference $17.9 \mathrm{pmol} / \mathrm{L}$ (Cl: 1.3-34.5, $P=0.037)$. (E) Plasma epinephrine levels were significantly higher in the patients after $1 \mathrm{~h}$ of exercise; mean difference $844 \mathrm{pmol} / \mathrm{L}$ (Cl: $412-1276$, $P=0.001)$. (F) In line with this, plasma norepinephrine levels were also increased in the patients; mean difference $4392 \mathrm{pmol} / \mathrm{L}(\mathrm{Cl}: 1140-7643, P=0.012)$. - , mean value; "significantly different from controls, $P<0.05$.

differ between patients and controls. Correspondingly, perceived exertion was maximal in all subjects.

\section{Metabolism during constant-load submaximal exercise}

Exercise conditions All subjects completed the 60 min of cycle ergometer exercise, and the patients and the controls carried out the same absolute workload, 33.0 (s.D. 17.9; range: 15-60) vs 31.4 (s.D. 16.8; range: 10-50) W, respectively $(P=0.902)$. Correspondingly, during exercise, the average oxygen consumption did not differ between

\begin{tabular}{|lr}
\hline http://www.endocrineconnections.org & ○ 2017 The authors \\
DOI: 10.1530/EC-17-0042 & Published by Bioscientifica Ltd
\end{tabular}

patients, $1021 \mathrm{~mL} / \mathrm{min}$ (s.D. 181; range: 867-1343) and controls, $972 \mathrm{~mL} / \mathrm{min}$ (s.D. 208; range: 707-1317; $P=0.805)$. The relative workload, however, was higher for the patients $(P<0.001)$, being $63.8 \%$ (s.D. 7.9 ; range: 53.9-76.2) of $\mathrm{VO}_{2 \text { peak }}$ vs $30.2 \%$ (s.D. 5.7; range: 23.0-39.8) for controls. In line with the exercise being relatively harder for the patients, during exercise, average heart rate was higher in the patients, 121 (s.D. 20.0; range: 99-147) vs 92 (S.D. 9.9; range: 87-106) beats/min in controls $(P=0.007)$, and the patients also rated exercise as being harder, 12.1 (s.D. 1.5; range: 10.0-14.3), than the controls did, 8.5 (s.D. 1.5; range: 7.0-10.9), Borg score $(P=0.001)$.

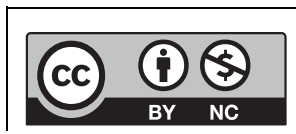

This work is licensed under a Creative Commons Attribution-NonCommercial 4.0 International License. 

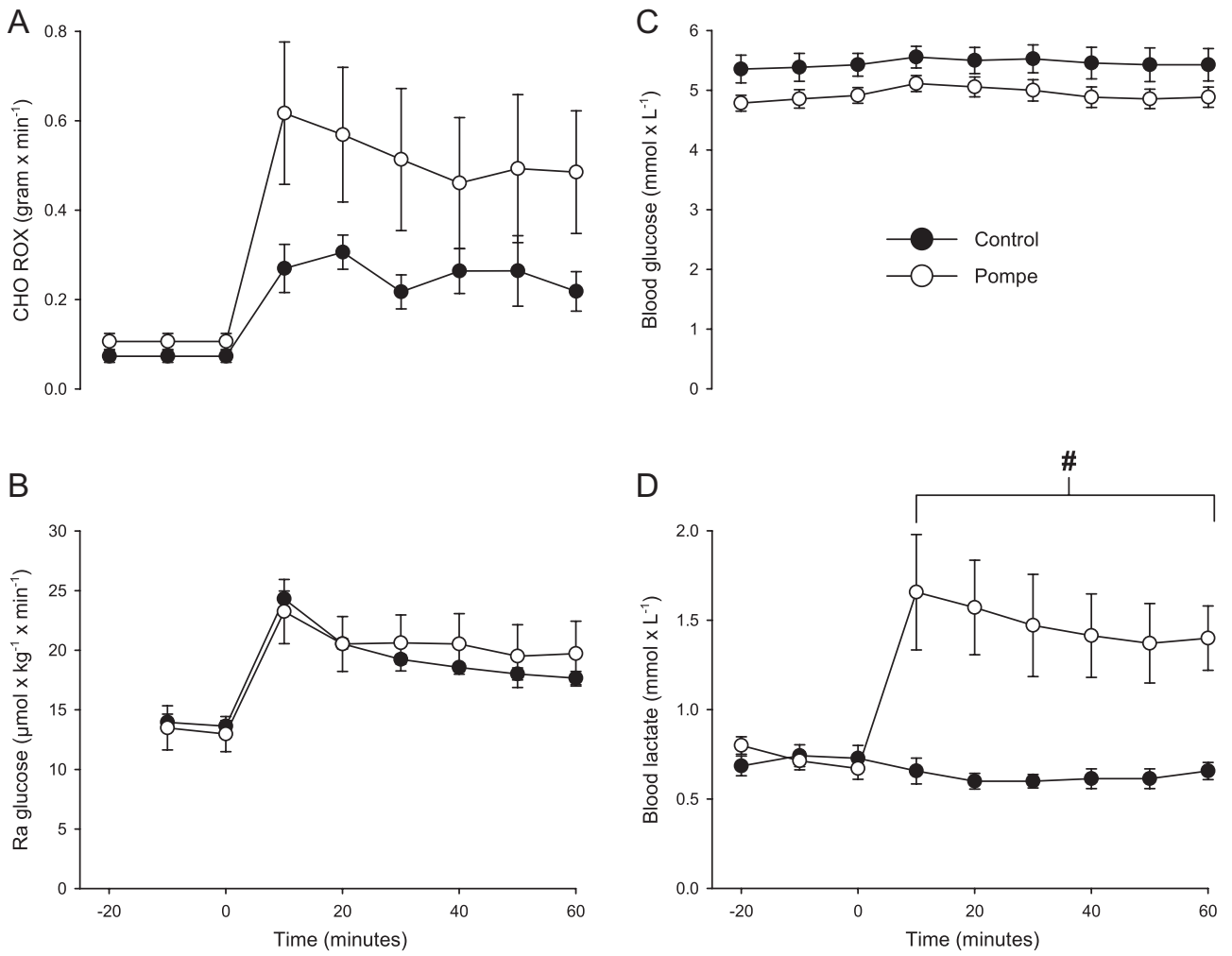

Figure 3

Carbohydrate metabolism and blood lactate levels during submaximal exercise. (A) The whole-body carbohydrate (CHO) rate of oxidation (ROX) was similar between patients and controls during exercise; mean difference $0.226 \mathrm{~g} / \mathrm{min}$ (Cl: 0.611 to $-0.078, P=0.318$ ). (B) The rate of appearance of glucose $\left(R_{a}\right)$, i.e. liver glucose output, was also similar between patients 20.7 (s.D. 6.6) and controls 19.6 (s.D. 1.2) $\mu \mathrm{mol} / \mathrm{kg} / \mathrm{min}$, respectively, during exercise; mean difference $1.1 \mu \mathrm{mol} / \mathrm{kg} / \mathrm{min}$ (Cl: 6.7 to $-4.4, P=0.902$ ). (C) Blood glucose levels during exercise remained stable in patients 5.0 (s.D. $0.4 ;$ range: $4.5-5.6)$ and controls 5.5 (s.D. 0.6 ; range: $5.0-6.8) \mathrm{mmol} / \mathrm{L}$, and there was no difference in blood glucose levels between groups $(P=0.128)$. (D) Blood lactate levels did not increase during exercise in controls; however, in the patients, the blood lactate levels rose significantly to a mean of 1.5 (s.D. 0.6$)$ vs 0.6 (s.D. $0.1) \mathrm{mmol} / \mathrm{L}$ in controls; mean difference $0.9 \mathrm{mmol} / \mathrm{L}$ (Cl: $0.3-1.4, P=0.001)$. Error bars are s.E.M. \#significantly different from controls during exercise $P<0.05$ (mean of whole exercise period).

Plasma palmitate enrichment reached similar levels at the same time (20 min before exercise) in both groups, 216 (s.D. 29) and 200 (s.D. 34) ${ }^{813} \mathrm{C} /{ }^{812} \mathrm{C}(P=0.736)$ in controls and patients, respectively, indicating that distribution volumes did not differ between groups (Figs 3 and 4).

\section{Carbohydrate metabolism during constant-load submaximal exercise}

During exercise, the rates of appearance and disappearance of glucose, i.e. liver glucose output and tissue glucose uptake, were similar within and between patients and controls, and, accordingly, blood glucose levels were similar between groups and remained stable throughout the full hour of exercise (Fig. 3). The average oxidation rates of carbohydrate were similar between patients and controls during exercise.

\section{Fatty acid and glycerol metabolism during submaximal exercise}

During exercise, the rate of oxidation (ROX) of palmitate and NEFAs were similar in patients and controls, and plasma palmitate and NEFA concentrations increased similarly in both groups. In agreement with this, the rate of appearance of glycerol, reflecting rate of lipolysis and rate of disappearance of glycerol (6.610 (s.D. 2.499) $\mathrm{mmol} /$ $\mathrm{kg} / \mathrm{min}$ in patients and 5.814 (s.D. 1.622$) \mu \mathrm{mol} / \mathrm{kg} / \mathrm{min}$ in controls, $P=0.620$ ), reflecting tissue uptake, did not differ between the groups. Plasma glycerol concentration increased during exercise to $\sim 1 / 3$ of NEFA levels, which is in accordance with 3 fatty acids being released from http://www.endocrineconnections.org
DOI: $10.1530 /$ EC-17-0042
(C) 2017 The authors Published by Bioscientifica Ltd
This work is licensed under a Creative Commons Attribution-NonCommercial 4.0 International License. 

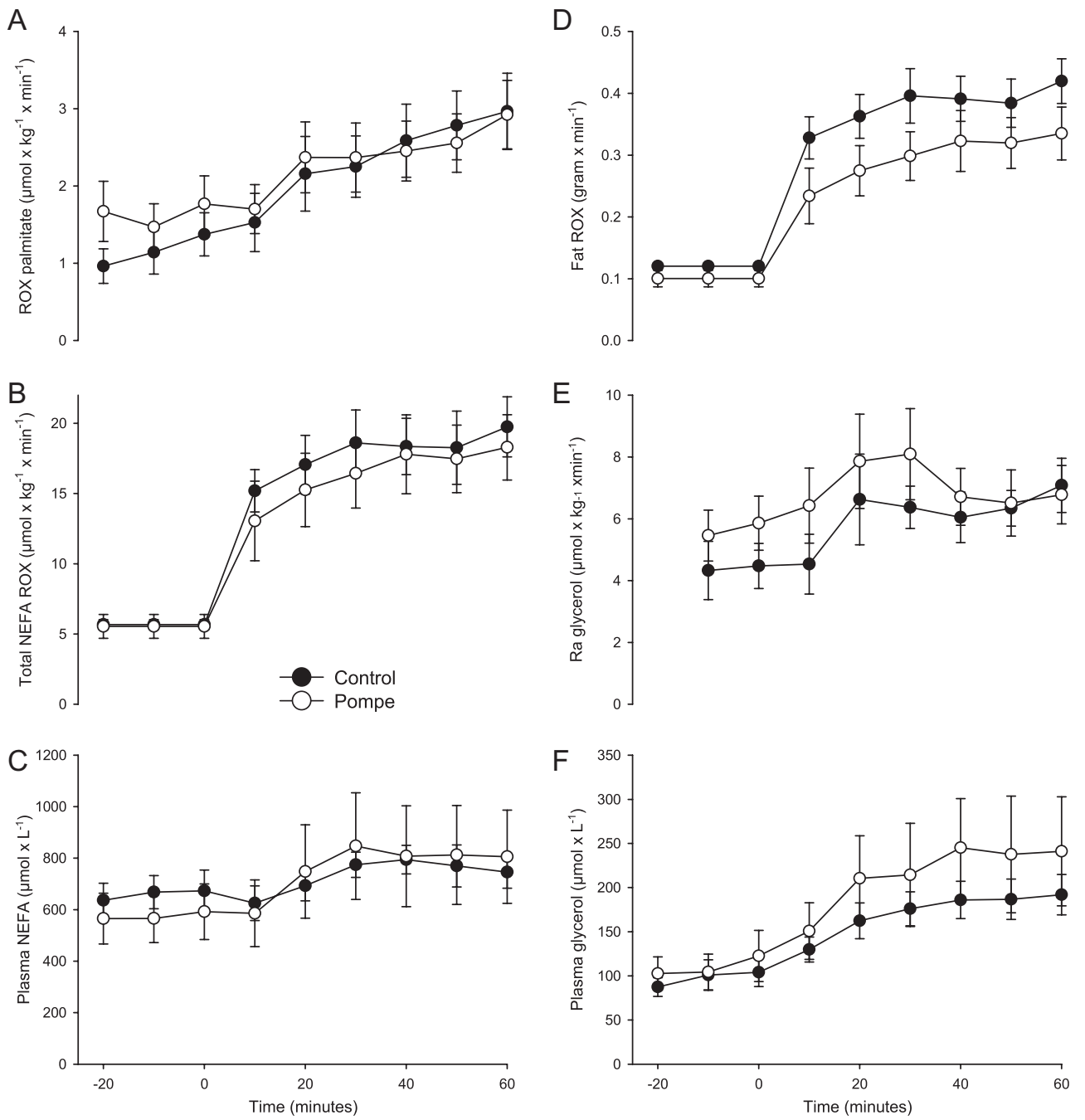

\section{Figure 4}

Fatty acid metabolism and glycerol turnover during submaximal exercise. (A) Average palmitate oxidation rate (ROX) in patients during exercise, 2.396 (s.D. 1.016) $\mu \mathrm{mol} / \mathrm{kg} / \mathrm{min}$ was similar to controls, 2.380 (s.D. 1.162) $\mu \mathrm{mol} / \mathrm{kg} / \mathrm{min}$; mean difference $0.016 \mu \mathrm{mol} / \mathrm{kg} / \mathrm{min}$ (Cl: 1.287 to $-1.255, P=0.710$ ).

(B) Oxidation rates of non-esterified fatty acids (NEFA) per kilo body weight did not differ between patients 16.4 (s.D. 6.6; range: 6.2-25.7) and controls 17.9 (s.D. 5.4; range: $13.1-29.3) \mu \mathrm{mol} / \mathrm{kg} / \mathrm{min}(P=0.805)$ during exercise. (C) The concentration of plasma NEFAs increased in patients $768 \mu \mathrm{mol} / \mathrm{L}$ (s.D. 466 ; range: $263-1496)$ and controls $734 \mu \mathrm{mol} / \mathrm{L}$ (s.D. 151; range: 493-963) $(P=0.710)$ during exercise. (D) ROX of fat $0.298 \mathrm{~g} / \mathrm{min}$ (s.D. 0.109) did not differ between patients and controls $0.380 \mathrm{~g} / \mathrm{min}$ (s.D. 0.095) (Cl: 0.036 to $-0.202, P=0.209)$. (E) The rate of appearance $\left(R_{\mathrm{a}}\right)$ of glycerol, reflecting adipose tissue lipolysis, was similar between patients $7.065 \mu \mathrm{mol} / \mathrm{kg} / \mathrm{min}$ (s.D. 2.728) and controls $6.168 \mu \mathrm{mol} / \mathrm{kg} / \mathrm{min}$ (s.D. 1.791), during exercise; mean difference 0.897 (95\% Cl: 3.584 to $-1.790 ; P=0.456)$. (F) Plasma glycerol concentrations were also similar during exercise in patients $217 \mu \mathrm{mol} / \mathrm{L}$ (s.D. $131 ;$ range: $417-55)$ and controls $172 \mu \mathrm{mol} / \mathrm{L}$ (s.D. 48; range: 108-260) $(P=0.456)$. Error bars are S.E.M.

each triglyceride molecule undergoing peripheral adipose tissue lipolysis (Fig. 4).

\section{Hormonal response to submaximal exercise}

End-exercise insulin levels were higher in the patients, but levels remained within normal range. At the end of exercise, epinephrine and norepinephrine levels were significantly higher in the patients (Fig. 2).

\section{Discussion}

The present study shows that patients with late-onset Pompe disease, caused by lysosomal alpha-glucosidase deficiency, have a markedly impaired maximal aerobic exercise capacity. On the other hand, the patients are able to tolerate prolonged submaximal exercise for $1 \mathrm{~h}$, which means that their endurance is normal (23). In contrast to other glycogenoses, in which markedly reduced peak 
oxidative work capacity reflects impaired glycogenolysis $(5,8,9,24,25)$, during maximal exercise, glycogenolysis was apparently adequate in the patients of the present study. Thus, at exhaustion upon graded exercise, blood lactate levels were high and the RER above $\geq 1$, indicating $100 \%$ carbohydrate combustion, as also found in controls. Rather than reflecting a metabolic block in substrate turnover, in Pompe disease, the impaired peak work performance is probably a direct consequence of the muscle wasting and weakness generally seen in the patients (5) and also demonstrated by body composition measurements (DEXA scanning) (Fig. 1) and clinical observations (Table 1 ) in the present study. The wasting likely reflects muscle fiber damage resulting from glycogen accumulation (26) as well as disuse (27). In line with this, baseline CK levels were slightly elevated, as it is expected in Pompe disease, reflecting the pathology of skeletal muscle damage in this myopathy $(2,26)$.

Impairment of glycogenolysis was not found during prolonged submaximal exercise in the patients with Pompe disease. Thus, at identical absolute workloads and, accordingly, energy needs, rates of total carbohydrate oxidation and plasma glucose turnover were similar in patients and controls (Fig. 3). Furthermore, during exercise in glycogenoses with significant blocks in muscle glycogenolytic capacity, i.e. Glycogenosis types IIIa, V, IXa and XIV, metabolism is shifted toward oxidation of fat $(9,11,12)$, but in the present study, no compensatory increases in plasma palmitate and overall fat oxidation were seen in the patients (Fig. 4). On the contrary, during exercise, carbohydrate metabolism, in fact, tended to be higher in patients compared with controls as judged from the total carbohydrate oxidation rates and the fact that the blood lactate concentration increased only in the patients (Fig. 3). These findings correspond with the fact that the workload in relative terms (\% of peak capacity) and, accordingly, plasma catecholamine concentrations (Fig. 2) $(28,29)$ were higher in patients than in controls.

During exercise, glycogen is mobilized from liver as well as muscle. Both tissues contain lysosomal alphaglucosidase as well as glycogen phosphorylase. However, the present findings, which were similar in patients with and without enzyme replacement therapy, confirm the view that during exercise glycogen phosphorylase rather than alpha-glucosidase is decisive for stimulation of glycogen breakdown in liver and muscle (11). In exercising human muscle, alpha-glucosidase is estimated to account for at most $8 \%$ of glycogen breakdown (30). Alpha-glucosidase activity has been shown to increase with exercise in trout liver, however, considerably less than glycogen phosphorylase activity (31).

After peak exercise, testing plasma CK concentration only increased in one patient, and endurance was normal in submaximal exercise. These findings indicate that moderate intensity aerobic exercise is safe in Pompe disease, and they extend observations from previous studies carried out at lower exercise intensities and durations $(32,33)$. Furthermore, our finding that unlike in other metabolic myopathies, skeletal muscle substrate use is normal during exercise, which renders exercise less complicated in Pompe disease.

Our patients were compared to a control group exercising at the same absolute workload as the patients, because a priori overall energy requirements and, accordingly, metabolism ought to be identical between groups (the 0-hypotheis). Comparisons between groups working at identical relative loads would be far more speculative, because relative work load is influenced by a multitude of internal and external factors, making the 0-hypothesis difficult to define. The dilemma of not being able to match controls to very weak patients, resulting in an inevitable difference in work capacity, is a common problem encountered in exercise studies of muscle diseases. The same relative workload in healthy subjects would have needed a much higher absolute workload and thus highly different energy turnover and substrate use in the controls, which in itself would skew the comparison. The relative work concept has been thoroughly elucidated in relation to physical training in healthy people $(29,35)$. While inactivity (i.e. too little training) may partly explain diminished $\mathrm{VO}_{2 \max }$ in various patient groups, also more specific disease characteristics may contribute making comparisons between patients and controls at identical relative loads difficult to interpret.

In conclusion, patients with late-onset Pompe disease have a markedly impaired maximal aerobic exercise capacity. On the other hand, the patients' ability to endure prolonged submaximal exercise at a moderate intensity is normal, because, unlike in other metabolic myopathies, in Pompe disease skeletal muscle substrate use is normal during exercise. This supports the view that during exercise glycogen phosphorylase rather than alpha-glucosidase is decisive for stimulation of glycogen breakdown in liver and muscle. Our findings encourage use of regular exercise in Pompe disease for recreational purposes as well as for improving physical function and health. http://www.endocrineconnections.org DOI: 10.1530/EC-17-0042
(C) 2017 The authors Published by Bioscientifica Ltd
This work is licensed under a Creative Commons Attribution-NonCommercial 4.0 International License. 


\section{Declaration of interest}

Dr Preisler reports having received research support and honoraria from the Genzyme Corporation. Dr Laforêt reports having received research support and honoraria from the Genzyme Corporation. Dr Laforêt is a member of the Genzyme Pompe Disease Advisory Board. Dr Madsen reports no disclosures. Dr Husu reports no disclosures. Dr Vissing CR reports no disclosures. Dr Hedermann reports no disclosures. Dr Galbo reports no disclosures. Dr Lindberg reports having received research support and honoraria from the Genzyme Corporation. Dr Vissing J reports having received research support and honoraria from the Genzyme Corporation. $\mathrm{He}$ is a member of the Genzyme Pompe Disease Advisory Board.

\section{Funding}

This work was supported by The Vanføre Foundation, The Family Hede Nielsen Foundation, Aase and Ejnar Danielsens Foundation, Merchant L F Foghts Foundation, and The A P Møller Foundation for the Advancement of Medical Science.

\section{Authors' contribution statement}

$\mathrm{N}$ Preisler contributed to design of the study, analysis, acquisition and interpretation of data, and drafting of the manuscript. P Laforet contributed to design of the study, acquisition of data and critical revision of the manuscript. K L Madsen contributed to design of study, acquisition of data, interpretation of data and critical revision of the manuscript. E Husu contributed to acquisition of data and critical revision of the manuscript. $C$ $\mathrm{R}$ Vissing and $\mathrm{G}$ Hedermann contributed to acquisition of data and critical revision of the manuscript. $\mathrm{H}$ Galbo helped in interpretation of data and critical revision of the manuscript. C Lindberg contributed to acquisition of data and critical revision of the manuscript. J Vissing contributed to design of study, interpretation of data and critical revision of the manuscript.

\section{Acknowledgements}

The authors thank Danuta Goralska-Olsen, Thomas Lauridsen, Nina Pluszek and Lene Foged for technical assistance and Malene Have for coordinating patient and investigator travel. Statistical analysis was conducted by Nicolai Preisler.

\section{References}

1 van der Ploeg AT \& Reuser AJ. Pompe's disease. Lancet 2008372 1342-1353. (doi:10.1016/S0140-6736(08)61555-X)

2 Winkel LP, Hagemans ML, van Doorn PA, Loonen MC, Hop WJ, Reuser AJ \& van der Ploeg AT. The natural course of non-classic Pompe's disease; a review of 225 published cases. Journal of Neurology 2005252 875-884. (doi:10.1007/s00415-005-0922-9)

3 van der Ploeg AT, Clemens PR, Corzo D, Escolar DM, Florence J, Groeneveld GJ, Herson S, Kishnani PS, Laforet P, Lake SL, et al. A randomized study of alglucosidase alfa in late-onset Pompe's disease. New England Journal of Medicine 2010362 1396-1406. (doi:10.1056) NEJMoa0909859)

4 Gungor D, de Vries JM, Hop WC, Reuser AJ, van Doorn PA, van der Ploeg AT \& Hagemans ML. Survival and associated factors in 268 adults with Pompe disease prior to treatment with enzyme replacement therapy. Orphanet Journal of Rare Diseases 2011634. (doi:10.1186/1750-1172-6-34)

5 Preisler N, Haller RG \& Vissing J. Exercise in muscle glycogen storage diseases. Journal of Inherited Metabolic Disease 201538 551-563. (doi:10.1007/s10545-014-9771-y)
6 Bergstrom J, Hermansen L, Hultman E \& Saltin B. Diet, muscle glycogen and physical performance. Acta Physiologica Scandinavica 196771 140-150. (doi:10.1111/j.1748-1716.1967.tb03720.x)

7 McArdle WD, Katch FI \& Katch VL. Energy transfer in the body. In Exercise Physiology: Energy, Nutrition, and Human Performance, edn 6th, pp 137-163. Eds WD McArdle, FI Katch \& VL Katch. Baltimore, MD, USA: Lippincott Williams \& Wilkins, 2007.

8 Preisler N, Madsen KL, Prahm KP, Laforet P, Hedermann G, Vissing CR, Galbo H \& Vissing J. Fat and carbohydrate metabolism during exercise in patients with Glycogen storage disease type III. Molecular Genetics and Metabolism 2013109 14-20. (doi:10.1016/j. ymgme.2013.02.008)

9 Preisler N, Laforet P, Echaniz-Laguna A, Orngreen MC, LonsdorferWolf E, Doutreleau S, Geny B, Stojkovic T, Piraud M, Petit FM, et al. Fat and carbohydrate metabolism during exercise in phosphoglucomutase type 1 deficiency. Journal of Clinical Endocrinology and Metabolism 201398 E1235-E1240. (doi:10.1210/ jc.2013-1651)

10 Preisler N, Orngreen MC, Echaniz-Laguna A, Laforet P, LonsdorferWolf E, Doutreleau S, Geny B, Akman HO, DiMauro S \& Vissing J. Muscle phosphorylase kinase deficiency: a neutral metabolic variant or a disease? Neurology 201278 265-268. (doi:10.1212/ WNL.0b013e31824365f9)

11 Orngreen MC, Jeppesen TD, Andersen ST, Taivassalo T, Hauerslev S, Preisler N, Haller RG, van HG \& Vissing J. Fat metabolism during exercise in patients with McArdle disease. Neurology 200972 718-724. (doi:10.1212/01.wnl.0000343002.74480.e4)

12 Preisler N, Laforet P, Madsen KL, Prahm KP, Hedermann G, Vissing CR, Galbo H \& Vissing J. Skeletal muscle metabolism is impaired during exercise in glycogen storage disease type III. Neurology $2015 \mathbf{8 4}$ 1767-1771. (doi:10.1212/wnl.0000000000001518)

13 Pascual JM \& Roe CR. Systemic metabolic abnormalities in adult-onset acid maltase deficiency: beyond muscle glycogen accumulation. JAMA Neurology 201370 756-763. (doi:10.1001/jamaneurol.2013.1507)

14 Abumrad NN, Rabin D, Diamond MP \& Lacy WW. Use of a heated superficial hand vein as an alternative site for the measurement of amino acid concentrations and for the study of glucose and alanine kinetics in man. Metabolism 198130 936-940. (doi:10.1016/00260495(81)90074-3)

15 Borg G. Perceived exertion as an indicator of somatic stress. Scandinavian Journal of Rehabilitation Medicine 19702 92-98.

16 Oehlke J, Brudel M \& Blasig IE. Benzoylation of sugars, polyols and amino acids in biological fluids for high-performance liquid chromatographic analysis. Journal of Chromatography B Biomedical Sciences and Applications 1994655 105-111. (doi:10.1016/03784347(94)00067-0)

17 Steele R. Influences of glucose loading and of injected insulin on hepatic glucose output. Annals of the New York Academy of Sciences 195982 420-430. (doi:10.1111/j.1749-6632.1959.tb44923.x)

18 van HG. Correction factors for 13C-labelled substrate oxidation at whole-body and muscle level. Proceedings of the Nutrition Society 1999 58 979-986. (doi:10.1017/s0029665199001299)

19 van Loon LJ, Koopman R, Schrauwen P, Stegen J \& Wagenmakers AJ. The use of the $[1,2-13 \mathrm{C}]$ acetate recovery factor in metabolic research. European Journal of Applied Physiology 200389 377-383. (doi:10.1007/ s00421-003-0810-x)

20 Peronnet F \& Massicotte D. Table of nonprotein respiratory quotient: an update. Canadian Journal of Sport Sciences 199116 23-29.

21 Preisler N, Laforet P, Madsen KL, Hansen RS, Lukacs Z, Orngreen MC, Lacour A \& Vissing J. Fat and carbohydrate metabolism during exercise in late-onset Pompe disease. Molecular Genetics and Metabolism 2012107 462-468. (doi:10.1016/j.ymgme.2012.08.019)

22 Dupont WD \& Plummer WD Jr. Power and sample size calculations. A review and computer program. Controlled Clinical Trials 199011 116-128. (doi:10.1016/0197-2456(90)90005-M)

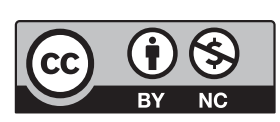

This work is licensed under a Creative Commons Attribution-NonCommercial 4.0 International License. 
23 Astrand PO, Rodal K, Dahl HA \& Stromme SB. Textbook of Work Physiology. Champaign, IL, USA: Human Kinetics, 2003.

24 Haller RG, Lewis SF, Cook JD \& Blomqvist CG. Myophosphorylase deficiency impairs muscle oxidative metabolism. Annals of Neurology 198517 196-199. (doi:10.1002/ana.410170216)

25 Haller RG \& Vissing J. Spontaneous 'second wind' and glucoseinduced second 'second wind' in McArdle disease: oxidative mechanisms. Archives of Neurology 200259 1395-1402. (doi:10.1212/01.WNL.0000031423.43482.19)

26 van den Berg LE, Drost MR, Schaart G, de LJ, van Doorn PA, van der Ploeg AT \& Reuser AJ. Muscle fiber-type distribution, fibertype-specific damage, and the Pompe disease phenotype. Journal of Inherited Metabolic Disease 201336 787-794. (doi:10.1007/s10545012-9541-7)

27 Stein TP \& Wade CE. Metabolic consequences of muscle disuse atrophy. Journal of Nutrition 2005135 1824S-1828S.

28 Christensen NJ, Galbo H, Hansen JF, Hesse B, Richter EA \& TrapJensen J. Catecholamines and exercise. Diabetes 197928 (Supplement 1) 58-62. (doi:10.2337/diab.28.1.S58)

29 Kjaer M, Bangsbo J, Lortie G \& Galbo H. Hormonal response to exercise in humans: influence of hypoxia and physical training. American Journal of Physiology 1988254 R197-R203.

30 Wahren J. Human forearm muscle metabolism during exercise. IV. Glucose uptake at different work intensities. Scandinavian
Journal of Clinical and Laboratory Investigation 197025 129-135. (doi:10.3109/00365517009049194)

31 Mehrani H \& Storey KB. Characterization of alpha-glucosidases from rainbow trout liver. Archives of Biochemistry and Biophysics $1993 \mathbf{3 0 6}$ 188-194. (doi:10.1006/abbi.1993.1499)

32 Terzis G, Dimopoulos F, Papadimas GK, Papadopoulos C, Spengos K, Fatouros I, Kavouras SA \& Manta P. Effect of aerobic and resistance exercise training on late-onset Pompe disease patients receiving enzyme replacement therapy. Molecular Genetics and Metabolism 2011104 279-283. (doi:10.1016/j. ymgme.2011.05.013)

33 van den Berg LE, Favejee MM, Wens SC, Kruijshaar ME, Praet SF Reuser AJ, Bussmann JB, van Doorn PA \& van der Ploeg AT. Safety and efficacy of exercise training in adults with Pompe disease: evalution of endurance, muscle strength and core stability before and after a 12 week training program. Orphanet Journal of Rare Diseases 20151087. (doi:10.1186/s13023-015-0303-0)

34 Gray KA, Yates B, Seal RL, Wright MW \& Bruford EA. Genenames. org: the HGNC resources in 2015. Nucleic Acids Research 201543 D1079-D1085. (doi:10.1093/nar/gku1071)

35 Stisen AB, Stougaard O, Langfort J, Helge JW, Sahlin K \& Madsen K. Maximal fat oxidation rates in endurance trained and untrained women. European Journal of Applied Physiology 200698 497-506. (doi:10.1007/s00421-006-0290-x)

\section{Received in final form 8 May 2017}

Accepted 10 May 2017

Accepted Preprint published online 10 May 2017 http://www.endocrineconnections.org DOI: 10.1530/EC-17-0042 (c) 2017 The authors Published by Bioscientifica Ltd

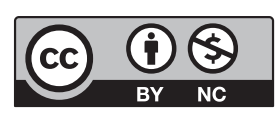

This work is licensed under a Creative Commons Attribution-NonCommercial 4.0 International License. 